УДК 339.137.2

DOI 10.35433/ISSN2410-3748-2019-1(24)-6

Л.Д. Павловська, к.е.н., професор, професор кафедри економіки, менеджменту та маркетингу Житомирський державний університет імені Івана Франка Н.К. Мрачковська, к.е.н., доцент, доцент кафедри фінансів Національний університет біоресурсів і природокористування України

\title{
ІМІДЖОВА СКЛАДОВА ЗРОСТАННЯ КОНКУРЕНТНОГО СТАТУСУ ПІДПРИЕМСТВА
}

\begin{abstract}
Досліджені теоретико-методичні та прикладні засади впливу іміджу підприємства на зростання його конкурентного статусу. Методом анкетування та індексного аналізу встановлено, щуо найсуттєвіший вплив на конкурентний статус підприємства має його іміджева позиція, яка серед розрахованих трьох складових конкурентного статусу має найбільше значення індексу - 1,268 порівняно з індексом конкурентної позииії м'ясопереробного підприємства, який дорівнює 1,045 та індексом ресурсної позииії, рівним 1. Досліджуване товариство займає досить високу іміджеву позицію, яка на 26,8 пунктів вища за середній рівень по області.

Задля подальшого зростання зовнішньої іміджевої позиції підприємству необхідно в першу чергу звернути увагу на маркетингові заходи, які є критичними з позиції споживачів - можливість знижок на товар, зниження иіни та покращення фірмового стилю; з позииії бізнес-партнерів - збільшувати інвестиційну привабливість та бути більш відкритими з точки зору інформованості та прозорості ведення бізнесу; з позииї органів державної влади - бути більш задіяними у державних програмах розвитку регіону. Покращити внутрішній імідж з позищіі співробітників підприємства допоможе: за сочіально-психологічним мікрокліматом - зниження конфліктності у колективі; серед чинників зростання іміджу керівних кадрів збільшення рівня інформачійної відкритості керівництва та лояльності до прачівників. Ключові слова: імідж, конкурентний статус, позиція, споживачі, бізнес-партнери, підприємство, органи державної влади, корпоративна культура, керівні кадри, індекс, опитування.
\end{abstract}

\section{THE IMAGE COMPONENT OF THE GROWTH OF THE COMPETITIVE STATUS OF THE ENTERPRISE}

The theoretical-methodical and applied principles of the enterprise's image influence on the growth of its competitive status are researched. The method of questioning and index analysis applied to show, that the most important influence on the competitive status of the enterprise has its image position, which among the estimated three components of the competitive status () Павловська Л.Д., Мрачковська Н.К. 
has the highest value of the index - 1,268 in comparison to the index, the competitive position of the meat-packing plant, that is equal to 1,045 and the index of the resource position, which is equal to 1. The investigated company has a quite high image position, which is on 26.8 points higher compare to the average level in the region.

For the further growth of the external image position of the company it is necessary to pay attention to marketing activities that are crusial 1) from the consumers' point of view, such as

the possibility of discounts, lower prices and corporate style improvement; 2) from the

business partners' point of view, such as increasing investment attraction and being more open in terms of business awareness and transparency; 3) from the state authorities point of the view is to be more involved in state programs of the region's development. The internal

image from the position of company employees will help to improve: for the sociopsychological microclimate - reducing conflicts in the team; among the factors of growth of the image of senior managers - raising the level of the management information transparency and loyalty to employees.

Key words: image, competitive status, position, consumers, business partners, enterprise, state authorities, corporate culture, management, index, questioning.

Постановка проблеми. Необхідною умовою досягнення підприємством стійкого і тривалого ділового успіху, зростання його конкурентного статусу є забезпечення високого корпоративного іміджу. За умов загострення конкуренції зростає увага до проблеми формування сильного іміджу, здатного надавати позитивний для підприємства вплив. Сильний імідж підприємства має ефект придбання організацією певної ринкової сили, тобто призводить до зниження чутливості до ціни. Стійкий імідж зменшує замінюваність товарів, що означає його захист від нападів конкурентів і зміцнення ринкової позиції щодо товарів-замінників. Міцний імідж полегшує доступ фірми до ресурсів різного роду: фінансових, інформаційних, людських, природних тощо.

Аналіз останніх досліджень та публікацій. Проблемам формування та зростання іміджу підприємства, становлення іміджелогії як наукової дисципліни, сутності імідж-образу, іміджмейкерству як професійному напряму присвятили свої роботи такі вітчизняні та зарубіжні вчені як Альошина I. В., Аснович Н. Г., Грант Р. М., Даулінг Г., Джи Б., Замятіна Н. В., Котлер Ф., Новиченкова Л., Полторак В. А., Примак Т. О., Приходченко Я. В., Харрісон Ш., Чуміков А. Н., Шаша О. I. та інші. Вони досліджували теоретико-прикладні аспекти іміджу підприємства, його (О) Павловська Л.Д., Мрачковська Н.К. 
впливу на результативність діяльності, рівень конкурентоспроможності підприємства.

Однак, у сучасній літературі недостатньо дослідженими залишаються методичні аспекти визначення іміджу, поглиблене вивчення іміджевої складової зростання конкурентного статусу підприємства, що і стало причиною вибору даної теми дослідження.

Формулювання цілей статті: дослідження теоретико-методичних та практичних засад впливу іміджу підприємства на зростання його конкурентного статусу.

Виклад основного матеріалу дослідження. Поняття іміджу підприємства включає дві складові. Описову (інформаційну) складову, яка представляє собою образ організації, або сукупність всіх уявлень (знань) про організацію. І складову, пов'язану зі ставленням, або оцінну складову. Оцінна складова існує в силу того, що інформація, яка зберігається в пам'яті, не сприймається байдуже, а пробуджує оцінки і емоції, які можуть мати різну інтенсивність, оскільки конкретні риси образу організації можуть викликати більш-менш сильні емоції, пов'язані з їх прийняттям або осудом. Люди оцінюють підприємство через призму свого минулого досвіду, ціннісних орієнтацій, загальноприйнятих норм i моральних принципів. Образ і оцінка піддаються лише умовному концептуальному розрізненню. У реальності вони нерозривно пов'язані і утворюють єдине ціле. Таким чином, за оцінкою Томілової М.В., імідж організації можна розглядати як існуючу у свідомості людей систему уявлень (образів) та оцінок, об'єктом яких вона є [1].

Шаша O.I. стверджує, що імідж підприємства - це спеціально проектований, заснований на особливостях діяльності, закономірностях, властивостях, перевагах, якостях та характеристиках образ певного об’єкту, який цілеспрямовано вводиться (закріплюється, вкорінюється) у

(с) Павловська Л.Д., Мрачковська Н.К. 
свідомість цільових аудиторій за допомогою комплексу маркетингових комунікацій. До цільових аудиторій відносять споживачів, постачальників, інвесторів, держструктури, ЗМI, персонал. Тому зусилля по створенню іміджу підприємства повинні зосереджуватися у двох напрямах: внутрішньому та зовнішньому [2, с. 66-67].

Узагальнюючи різні погляди, Замятіна Н. В. пропонує визначити імідж підприємства як сформоване представлення цільовій аудиторії інформації про діяльність та успіхи підприємства, яке постійно та динамічно впливає на взаємини підприємства 3 групами суб'єктів взаємодії, на його конкурентоспроможність, фінансові результати та контакти 3 іншими державними або приватними підприємствами, установами та організаціями [3, с. 101-102].

Більшість авторів підкреслюють, що специфічність іміджу як атрибуту підприємства проявляється у тому, що він існує незалежно від зусиль самого підприємства навіть, якщо не розробляється спеціально [4, с. 10-11; 5, с. 13-14; 6, с. 7 та ін.]. В основному всі автори виділяють наступні етапи створення, формування, управління іміджем підприємства: оцінка поточної ситуації (обов'язковим є аналіз цільових аудиторій організації), постановка цілей, вибір цільових аудиторій, реалізація, оцінка та контроль результатів.

Специфічність іміджу як атрибуту підприємства проявляється у тому, що він існує незалежно від зусиль самого підприємства (він є, навіть, якщо i не розробляється спеціально, питання тільки - який) i, отже, потребує постійної оцінки та корекції.

Імідж формується по-різному для різних груп громадськості, оскільки бажана поведінка цих груп щодо підприємства може відрізнятися. Інакше кажучи, одне і те ж підприємство може по-різному сприйматися споживачами, інвесторами, держструктурами, місцевою та міжнародною

() Павловська Л.Д., Мрачковська Н.К. 
громадськістю. Наприклад, для широкої національної громадськості кращою є громадянська позиція підприємства. Для партнерів важливі надійність і конструктивність. Крім того, існує уявлення персоналу про своє підприємство і його керівництво. Таким чином, можна зазначити, що підприємство має кілька іміджів: для кожної групи громадськості - свій. Синтез уявлень про підприємство, властивих різним групам громадськості, створює більш загальне і ємне уявлення про підприємство, яке можна назвати його корпоративним іміджем.

Іміджом підприємства у споживачів $\epsilon$ уявлення людей щодо унікальних характеристик, які, на їхню думку, має продукція підприємства: якість, дизайн, популярність торгової марки; сервісні послуги та система знижок, що надаються підприємством; ціна на продукцію; уявлення споживачів про заявлену місії та стратегії підприємства, а також його фірмовий стиль.

На сучасному етапі існує декілька методів оцінки іміджу підприємства. Найбільш відомі такі: за допомогою семантичного диференціала, які пропагували Котлер Ф., Дагаєва Е. та ін. [7, с. 561-562; 6]; за допомогою шкал - Котлер Ф., Рогалева Н.Л. та ін. [7, с. 561; 6, с. $12-$ 14]; за допомогою розрахунку інтегральних показників - Герасимова Т.В., Рогалева Н.Л., Брежнева В.М. [5, с. 12-13; 6, с. 14-15; 9, с. 16-17]; метод вартісної оцінки іміджу через визначення вартості goodwill - Рогалева Н.Л. [6].

Практичне оцінювання імідж-позиції підприємства проведено на прикладі м'ясопереробного підприємства - ТОВ «Верест», що розташоване у м. Дунаївці Дунаєвського району Хмельницької області, і $€$ провідним підприємством для досліджуваної галузі, оскільки його питома вага у загальнообласному обсязі виробництва продукції становить майже $30 \%$. Інтегральний показник конкурентної (ринкової) позиції за 5 останніх

(с) Павловська Л.Д., Мрачковська Н.К. 
років вищий від середнього рівня по області, оскільки індекс конкурентної позиції більший 1 і складає 1,045.

Оцінювання імідж-позиції м’ясопереробного підприємства здійснено виходячи зі змісту структури останньої: зовнішній імідж, який характеризує рівень сприйняття підприємства споживачами, бізнеспартнерами, органами державної влади тощо, та внутрішній, що відображає ставлення до нього з боку персоналу. 3 цією метою на базі ТОВ «Верест» проведено соціологічне дослідження. Кількісний вимір наведених в анкетах показників здійснювали у балах: мінімальне значення - 0, а максимальне - 10. Це дозволило розрахувати по кожному напряму дослідження узагальнюючий та інтегральний показник імідж-позиції підприємства.

Так, для оцінювання зовнішнього іміджу ТОВ «Верест» проведено анкетне опитування 100 респондентів. Отримані результати щодо оцінки іміджу підприємства з позиції споживачів наведено в табл. 1.

Таблицуя 1

Оцінка іміджу досліджуваного підприсмства $з$ позиції споживачів

\begin{tabular}{|l|c|c|}
\hline \multicolumn{1}{|c|}{ Показник } & Значення, балів & Індекс оцінки \\
\hline Якість товару & 8,47 & 0,847 \\
\hline Безпечність товару & 8,22 & 0,822 \\
\hline Доступність товару за ціною для споживача & 7,55 & 0,755 \\
\hline Дієвість знижок на товар & 6,01 & 0,601 \\
\hline Популярність торгової марки & 8,38 & 0,838 \\
\hline Фірмовий стиль & 7,88 & 0,788 \\
\hline Імідж підприємства для споживачів & 46,51 & 0,775 \\
\hline
\end{tabular}

Джерело: розраховано за даними соціологічного дослідження

Імідж досліджуваного підприємства 3 позиції споживачів оцінено у 46,51 балів із 60 можливих, індекс іміджу підприємства становить 0,775. Найнижчою є оцінка споживачів щодо дієвості знижок на товар - 6,01 () Павловська Л.Д., Мрачковська Н.К. 
балів із 10 можливих або 0,601 індекс оцінки, доступності товару за ціною - відповідно 7,55 балів та 0,755, фірмового стилю - 7,88 балів та 0,788. При цьому найвищі оцінки споживачі надали якості товару - 8,47 балів та 0,847 індекс оцінки, популярності торгової марки - відповідно 8,38 балів та 0,838 , безпечності товару $-8,22$ балів та 0,822 . Все вищезазначене свідчить про досить високу оцінку споживачами м'ясної продукції ТОВ «Верест» та резерви зростання іміджу у напряму покращення фірмового стилю та посилення окремих маркетингових заходів підприємства.

3 позиції бізнес-партнерів імідж підприємства оцінено у 36,54 балів iз 50 можливих, що відповідає індексу оцінки - 0,731, тобто оцінка бізнеспартнерів майже на тому ж рівні, що і споживачів, але за іншими критеріями (табл. 2).

Таблиия 2

Оцінка іміджу досліджуваного підприємства 3 позиції бізнес-партнерів

\begin{tabular}{|l|c|c|}
\hline \multicolumn{1}{|c|}{ Показник } & Значення, балів & Індекс оцінки \\
\hline Надійність підприємства & 8,17 & 0,817 \\
\hline Інвестиційна привабливість & 6,33 & 0,633 \\
\hline Інформованість щодо місії підприємства & 6,84 & 0,684 \\
\hline Прозорість ведення бізнесу & 6,86 & 0,686 \\
\hline Престиж підприємства з позиції бізнес-партнерів & 8,34 & 0,834 \\
\hline Імідж підприємства для бізнес-партнерів & 36,54 & 0,731 \\
\hline
\end{tabular}

Джерело: розраховано за даними соціологічного дослідження

Невисоко оцінили партнери 3 бізнесу інвестиційну привабливість підприємства - 6,33 балів із 10 можливих, індекс оцінки - 0,633; інформованість щодо місії підприємства - 6,84 балів, індекс оцінки 0,684; прозорість ведення бізнесу - 6,86 балів, індекс оцінки - 0,686. Разом 3 тим, досить високо оцінено надійність підприємства $-8,17$ балів, індекс оцінки - 0,817 та його престиж - відповідно 8,34 балів та 0,834 .

(с) Павловська Л.Д., Мрачковська Н.К. 
Найвищою порівняно зі споживачами та бізнес-партнерами є оцінка іміджу досліджуваного підприємства 3 позиції органів державної влади, яка становить 38,79 балів із 50 можливих, тобто індекс оцінки складає 0,776 (табл. 3). Так, досить високою є оцінка продукції підприємства для регіону - 8,06 балів, що відповідає індексу оцінки - 0,806; дотримання екологічних вимог і нормативів оцінено у 8,07 балів, індекс оцінки - 0,807. Трохи нижчою є оцінка підприємства щодо участі у державних програмах розвитку регіону - 7,19 балів, індекс оцінки - 0,719 та соціальної активності - 7,56 балів, індекс оцінки - 0,756.

\section{Таблицуя 3}

\section{Оцінка іміджу досліджуваного підприсмства 3 позиції органів державної влади}

\begin{tabular}{|l|c|c|}
\hline \multicolumn{1}{|c|}{ Показник } & Значення, балів & Індекс оцінки \\
\hline Значення продукції підприємства для регіону & 8,06 & 0,806 \\
\hline Участь у державних програмах розвитку регіону & 7,19 & 0,719 \\
\hline Рівень виконання вимог чинного законодавства & 7,91 & 0,791 \\
\hline Соціальна активність підприємства & 7,56 & 0,756 \\
\hline Дотримання екологічних вимог і стандартів & 8,07 & 0,807 \\
\hline Імідж підприємства для органів державної влади & 38,79 & 0,776 \\
\hline
\end{tabular}

Джерело: розраховано за даними соціологічного дослідження

Інтегральний показник зовнішньог іміджу базового м’ясопереробного підприємства Хмельницької області визначено за формулою:

$$
\mathrm{I}_{3 \mathrm{I}}=\sqrt[3]{\mathrm{I}_{\text {СП }} \cdot \mathrm{I}_{\text {БП }} \cdot \mathrm{I}_{\text {дС }}}
$$

де I $_{3 \text { I }}$ - індекс зовнішнього іміджу м’ясопереробного підприємства;

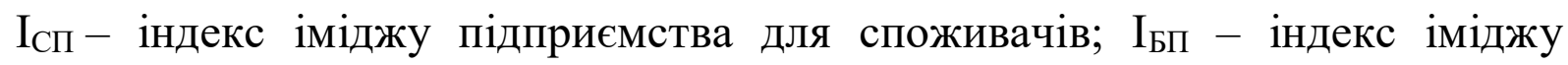
підприємства для бізнес-партнерів; І дс - індекс іміджу підприємства для органів державної влади.

() Павловська Л.Д., Мрачковська Н.К. 
$\mathrm{I}_{3 \mathrm{I}}=0,764$

Результати розрахунків свідчать, що значення зовнішнього іміджу ТОВ «Верест» Хмельницької області складає 0,764, що в перерахунку на шкалу оцінки конкурентної (ринкової) та ресурсної позиції підприємства становить 1,16 або на 16 пунктів більше за середній рівень по області.

Внутрішній імідж ТОВ «Верест» оцінено шляхом анкетного опитування 50 респондентів, які працюють у підприємстві, за такими основними об'єктами: корпоративна культура, соціально-психологічний мікроклімат, імідж керівних кадрів підприємства. Результати оцінювання корпоративної культури підприємства наведено в табл. 4.

Таблицяя 4

Оцінка іміджу досліджуваного підприсмства за корпоративною культурою

\begin{tabular}{|l|c|c|}
\hline \multicolumn{1}{|c|}{ Показник } & Значення, балів & Індекс оцінки \\
\hline Дієвість системи добору і навчання персоналу & 8,90 & 0,890 \\
\hline $\begin{array}{l}\text { Прозорість та демократичність відносин на } \\
\text { всіх рівнях ієрархії }\end{array}$ & 8,76 & 0,876 \\
\hline $\begin{array}{l}\text { Результативність системи атестації } \\
\text { працівників }\end{array}$ & 9,04 & 0,904 \\
\hline $\begin{array}{l}\text { Дієвість системи винагород та соціальних } \\
\text { пільг }\end{array}$ & 8,70 & 0,870 \\
\hline $\begin{array}{l}\text { Міра ідентифікації працівників з місією } \\
\text { підприємства }\end{array}$ & 8,68 & 0,868 \\
\hline $\begin{array}{l}\text { Імідж підприємства за корпоративною } \\
\text { культурою }\end{array}$ & 44,08 & 0,882 \\
\hline
\end{tabular}

Джерело: розраховано за даними соціологічного дослідження

Очевидно, що імідж ТОВ «Верест» за корпоративною культурою досить високий: бал оцінки становить 44,08 iз 50 можливих, тобто індекс іміджу підприємства за даним критерієм складає 0,882, що є наслідком високої оцінки системи атестації працівників - 9,04 балів із 10 можливих, індекс оцінки - 0,904; системи добору і навчання персоналу - відповідно 8,9 балів та 0,89; прозорості та демократичності відносин на всіх рівнях (с Павловська Л.Д., Мрачковська Н.К. 
ієрархії - 8,76 балів та 0,876 індекс оцінки. При цьому системі винагород та соціальних пільг надали дещо менше балів - 8,7 та 0,87 відповідно, а ступінь ідентифікації працівників 3 місією підприємства оцінили на 8,68 балів та 0,868 індекс оцінки.

Соціально-психологічний мікроклімат підприємства досліджено за показниками: дієвість системи попередження (зниження) конфліктності у колективі працівників; ступінь комфортності праці; дієвість системи культурно-психологічних заходів, тобто ступінь впровадження ціннісних орієнтацій і соціально-психологічних настанов (табл. 5). Працівники підприємства оцінили імідж ТОВ «Верест» за соціально-психологічним мікрокліматом у 23,5 балів із 30 можливих, тобто індекс іміджу складає 0,783. Зумовлено дане явище невисокою оцінкою системи попередження

Таблиия 5

Оцінка іміджу досліджуваного підприємства за соціальнопсихологічним мікрокліматом

\begin{tabular}{|l|c|c|}
\hline \multicolumn{1}{|c|}{ Показник } & Значення, балів & Індекс оцінки \\
\hline $\begin{array}{l}\text { Дієвість системи попередження (зниження) } \\
\text { конфліктності у колективі працівників }\end{array}$ & 6,38 & 0,638 \\
\hline Ступінь комфортності праці & 8,70 & 0,870 \\
\hline $\begin{array}{l}\text { Дієвість системи культурно-психологічних } \\
\text { заходів }\end{array}$ & 8,42 & 0,842 \\
\hline $\begin{array}{l}\text { Імідж підприємства за соціально- } \\
\text { психологічним мікрокліматом }\end{array}$ & 23,50 & 0,783 \\
\hline
\end{tabular}

Джерело: розраховано за даними соціологічного дослідження

(зниження) конфліктності у колективі працівників - 6,38 балів із 10 можливих, 0,638 індекс оцінки. При цьому ступінь комфортності праці та дієвість системи культурно-психологічних заходів оцінені досить високо відповідно 8,7 та 8,42 балів, 0,87 та 0,842 - індекс оцінки.

За іміджем керівних кадрів ТОВ «Верест» оцінено у 35,08 балів із 40 можливих, тобто індекс оцінки є досить високим та складає 0,877 (табл. 6).

() Павловська Л.Д., Мрачковська Н.К. 
Оцінка іміджу керівних кадрів ТОВ «Верест»

Таблиця 6

\begin{tabular}{|l|c|c|}
\hline \multicolumn{1}{|c|}{ Показник } & Значення, балів & Індекс оцінки \\
\hline Ступінь лояльності до працівників & 8,70 & 0,870 \\
\hline Рівень інформаційної відкритості керівництва & 8,44 & 0,844 \\
\hline $\begin{array}{l}\text { Міра ідентифікації керівних кадрів з місією } \\
\text { підприємства }\end{array}$ & 8,80 & 0,880 \\
\hline Культурно-психологічний рівень керівництва & 9,14 & 0,914 \\
\hline Імідж керівних кадрів підприємства & 35,08 & 0,877 \\
\hline
\end{tabular}

Джерело: розраховано за даними соціологічного дослідження

Спричинено це високою оцінкою культурно-психологічного рівня керівництва - 9,14 балів із 10 можливих, 0,914 індекс оцінки, ступеня ідентифікації керівних кадрів 3 місією підприємства $-8,8$ балів та 0,88 відповідно, рівня лояльності до працівників - 8,7 балів та 0,87 індекс оцінки.

Таким чином, інтегральний показник внутрішнього іміджу ТОВ «Верест» склав 0,854, що в перерахунку на шкалу оцінки конкурентної (ринкової) та ресурсної позиції підприємства становить 1,385, або на 38,5 пунктів більший за середній рівень.

Загальну імідж-позицію базового м’ясопереробного підприємства Хмельницької області визначено за формулою:

$$
\mathrm{I}_{\mathrm{III}}=\sqrt[2]{\mathrm{I}_{3 \mathrm{I}} \cdot \mathrm{I}_{\mathrm{BI}}},
$$

де $\mathrm{I}_{\text {II }}$ - індекс імідж-позиції м'ясопереробного підприємства; $\mathrm{I}_{3 \mathrm{I}}$ індекс зовнішнього іміджу підприємства; $\mathrm{I}_{\mathrm{BI}}$ - індекс внутрішнього іміджу підприємства.

$$
\mathrm{I}_{\mathrm{II}}=1,268
$$

Результати розрахунків свідчать, що імідж-позиція ТОВ «Верест» становить 1,268 , або на 26,8 пунктів вища за середній рівень.

() Павловська Л.Д., Мрачковська Н.К. 
Проведені дослідження дозволили розрахувати інтегральний показник конкурентного статусу базового м’ясопереробного підприємства Хмельницької області ( $\left.\mathrm{I}_{\kappa \mathrm{C}}\right)$, який обчислено за формулою:

$$
\mathrm{I}_{\mathrm{KC}}=\sqrt[3]{\mathrm{I}_{\mathrm{K \Pi}} \cdot \mathrm{I}_{\mathrm{P \Pi}} \cdot \mathrm{I}_{\mathrm{I \Pi}}}
$$

де $\mathrm{I}_{\kappa с}$ - індекс конкурентного статусу; $\mathrm{I}_{\text {КП }}$ - індекс конкурентної (ринкової) позиції м’ясопереробного підприємства; І Рп - індекс ресурсної позиції; ІІп - індекс імідж-позиції.

$$
\sqrt[3]{1,045 * 1 * 1,268}=1,073
$$

Отже, індекс конкурентного статусу ТОВ «Верест» склав 1,073, що на 7,3 пунктів більше за середнє значення. Це $є$ наслідком вищої за середній рівень конкурентної позиції та імідж-позиції підприємства значення індексів відповідно становить 1,045 і 1,268.

Резервами підвищення конкурентного статусу м'ясопереробних підприємств Хмельницької області, що виявлені внаслідок виміру та оцінювання їх конкурентної (ринкової), ресурсної та імідж-позиції, є наступні: покращення рівня забезпеченості підприємства виробничими ресурсами; зростання ефективності виробничо-збутової діяльності та зміцнення фінансового стану підприємства; удосконалення існуючої на підприємстві маркетингової політики в частині застосовуваних знижок на товар, посилення співпраці з органами державної влади щодо реалізації соціальних та інших програм розвитку регіону, удосконалення системи мотивації та соціального забезпечення працівників.

Висновки. Проведені дослідження свідчать, що найсуттєвіший вплив на конкурентний статус підприємства має його іміджева позиція, яка серед розрахованих трьох складових конкурентного статусу має найбільше значення індексу - 1,268 порівняно 3 індексом конкурентної (ринкової) позиції м’ясопереробного підприємства, який дорівнює 1,045 та індексом ресурсної позиції, рівним 1. Досліджуване товариство займає

() Павловська Л.Д., Мрачковська Н.К. 
досить високу іміджеву позицію, яка на 26,8 пунктів вища за середній рівень по області.

Задля подальшого зростання зовнішньої іміджевої позиції підприємству необхідно в першу чергу звернути увагу на маркетингові заходи, які є критичними з позиції споживачів - можливість знижок та товар, зниження ціни та покращення фірмового стилю; 3 позиції бізнеспартнерів - збільшувати інвестиційну привабливість та бути більш відкритими з точки зору інформованості та прозорості ведення бізнесу; 3 позиції органів державної влади - бути більш задіяними у державних програмах розвитку регіону. Покращити внутрішній імідж 3 позиції співробітників підприємства, за якою імідж отримав найвищі оцінки, допоможе за соціально-психологічним мікрокліматом - зниження конфліктності у колективі; серед чинників зростання іміджу керівних кадрів - збільшення рівня інформаційної відкритості керівництва та лояльності до працівників.

\section{Список використаних джерел:}

1. Томилова М.В. Модель имиджа организации [Електронний ресурс]. Режим доступу : http://www.cfin.ru/press/marketing/1998-1/05.shtml. Назва з екрану.

2. Шаша О. I. Корпоративна соціальна відповідальність як фактор формування позитивного іміджу підприємства / Шаша О. I. // Науковий збірник Харківського технічного університету, 2012. - №2. - С. 65-69.

3. Замятіна Н. В. Формування позитивного іміджу як фактор забезпечення конкурентоспроможності туристичного підприємства // Економіка та управління підприємствами, с. 99-108. Випуск IV (68), 2017, с. 99-108. [Електронний ресурс]. Режим доступу: $\underline{\text { http://chtei- }}$ 
knteu.cv.ua/herald/content/download/archive/2017/v4/12.pdf. - Назва 3 екрану.

4. Якубенко Е.Н. Формирование и мониторинг корпоративного имиджа промышленного предприятия: автореф. дис. канд. экон. наук / Якубенко Елена Николаевна. - Брянск: Брянск. гос. ун-т им. акад. И.Г. Петровского, 2006. - 24 с.

5. Герасимова Т.В. Теоретико-методологические основы формирования имиджевой политики хозяйствующего субъекта: автореф. дис. канд. экон. наук / Герасимова Татьяна Викторовна. - М.: РЭА им. Г.В. Плеханова, 2007. - 22 с.

6. Рогалева Н.Л. Современная концепция имиджа организации [Электронный ресурс] - Режим доступа: http://www.sovetnik.ru/konkurs/places/raso4/?id=104\&type=view . - Назва з екрану.

7. Котлер Ф. Маркетинг менеджмент: пер. с англ. / под ред. Л. А. Волковой, Ю. Н. Каптуревского. - СПб.: Питер, 2000. - 752 с.

8. Дагаева Е. Управление имиджем вуза [Электронный ресурс] Режим доступа: http://www.top-personal.ru/issue.html?377. - Назва з екрану.

9. Брежнева В.M. Формирование и развитие имиджа организаций потребительской кооперации: автореф. дис. канд. экон. наук / В.М. Брежнева. - Белгород: Белгор. ун-т потреб. коопер., 2007. - 26 с.

10. Оценка и формирование корпоративного имиджа предприятия [Электронный ресурс] Режим доступа:

http://www.cfin.ru/press/marketing/2001-3/12.shtml. - Назва з екрану.

\section{REFERENCES:}

1. Tomylova M.V. Model ymydzha orhanyzatsyy Retrieved from http://www.cfin.ru/press/marketing/1998-1/05.shtml [in Russian].

( Павловська Л.Д., Мрачковська Н.К. 
2. Shasha O. I. Korporatyvna sotsialna vidpovidalnist yak faktor formuvannia pozytyvnoho imidzhu pidpryiemstva / Shasha O. I. // Naukovyi zbirnyk Kharkivskoho tekhnichnoho universytetu, 2012. - \#2. - S. 65-69.

3. Zamiatina N. V. Formuvannia pozytyvnoho imidzhu yak faktor zabezpechennia konkurentospromozhnosti turystychnoho pidpryiemstva // Ekonomika ta upravlinnia pidpryiemstvamy, s. 99-108. Vypusk IV (68), 2017, s. 99-108. [Elektronnyi resurs]. Rezhym dostupu: http://chteiknteu.cv.ua/herald/content/download/archive/2017/v4/12.pdf

4. Yakubenko E.N. Formyrovanye y monytorynh korporatyvnoho ymydzha prombshlennoho predpryiatyia: avtoref. dys. kand. эkon. nauk / Yakubenko Elena Nykolaevna. - Briansk: Briansk. hos. un-t ym. akad. Y.H. Petrovskoho, 2006. $-24 \mathrm{~s}$.

5. Herasymova T.V. Teoretyko-metodolohycheskye osnovы formyrovanyia ymydzhevoi polytyky khoziaistvuiushcheho subъekta: avtoref. dys. kand. эkon. nauk / Herasymova Tatiana Vyktorovna. - M.: RЭA ym. H.V. Plekhanova, 2007. - 22 s.

6. Rohaleva N.L. Sovremennaia kontseptsyia ymydzha orhanyzatsyy [Эlektronnыi resurs] / N. L. Rohaleva. - Rezhym dostupa: http://www.sovetnik.ru/konkurs/places/raso4/?id=104\&type=view.

7. Kotler F. Marketynh menedzhment: per. s anhl. / pod red. L. A. Volkovoi, Yu. N. Kapturevskoho. - SPb.: Pyter, 2000. - 752 s.

8. Dahaeva E. Upravlenye ymydzhem vuza [Эlektronnыi resurs] / E. Dahaeva. Rezhym dostupa: http://www.top-personal.ru/issue.html?377

9. Brezhneva V.M. Formyrovanye y razvytye ymydzha orhanyzatsyi potrebytelskoi kooperatsyy: avtoref. dys. kand. эkon. nauk / V.M. Brezhneva. - Belhorod: Belhor. un-t potreb. kooper., 2007. - 26 s.

10. Otsenka y formyrovanye korporatyvnoho ymydzha predpryiatyia http://www.cfin.ru/press/marketing/2001-3/12.shtml

() Павловська Л.Д., Мрачковська Н.К. 